\title{
Characterization and variations of organic parameters in teleost fish endolymph during day-night cycle, starvation and stress conditions
}

\author{
Marielle Guibbolini ${ }^{\underline{a}}$, Gil Borelli ${ }^{a}$, Nicole Mayer-Gostan ${ }^{\mathrm{a}}$, Fabrice Priouzeau ${ }^{\mathrm{a}}$, Hélène De Pontual ${ }^{\underline{b}}$, \\ Denis Allemand ${ }^{\underline{a}, \underline{c}}$ and Patrick Payan ${ }^{\underline{a}}$
}

\author{
aUMR INRA-UNSA N¹112, Laboratoire ROSE, Université de Nice-Sophia Antipolis, Faculté des Sciences, Parc \\ Valrose, 06108 Nice Cedex 2, France \\ ${ }^{\mathrm{b}}$ IFREMER, DRV, RH, Laboratoire de Sclérochronologie des Animaux Aquatiques, BP 70, 29280 Plouzané, \\ France \\ ${ }^{\mathrm{C}}$ Centre Scientifique de Monaco, Avenue Saint-Martin, MC 98000, Monaco
}

Corresponding author : guibboli@unice.fr

\begin{abstract}
:
The aim of the present work was to examine the modifications of the organic composition of fish endolymph under environmental conditions (day-night cycle, starvation and $\mathrm{Cl}_{2}$-stress) known to modify otolith growth. Endolymph electrophoretic patterns were compared. An antibody raised against the trout otolith organic matrix allowed examining the variations of organic matrix precursors in the endolymph under the above conditions. Western blot analysis showed bands around $60-80 \mathrm{kDa}$. A $50 \%$ decrease of immunolabelling was observed during the night whereas increases were seen after starvation (factor 3 ) or stress (factor 2) suggesting that these variations could be related to the organic matrix deposit. A factor retarding in vitro $\mathrm{CaCO}_{3}$ crystallization (FRC) was shown to co-precipitate with endolymph proteins and its apparent molecular mass (determined by measuring the activity after electro elution of gel electrophoresis) was estimated around $20 \mathrm{kDa}$. The FRC activity was stable during day-night cycle whereas it decreased by $70 \%$ and nearly $100 \%$ under starvation and stress respectively. These results suggest that the FRC, although retarding in vitro crystallization, plays a major role in the process of otolith calcification and that the decreases measured after starvation and stress are responsible for the decreases of the otolith growth. The variations of these two parameters (precursors and FRC) could contribute for the changes in the microstructure of the otolith
\end{abstract}

Keywords: Endolymph; In vitro crystallization; Otolith calcification; Organic matrix; Day-night cycle; Starvation; Stress; Trout; Turbot 


\section{Introduction}

The inner ear is composed of 3 semi-circular canals and 3 compartments (utricule, saccule and lagena), each one containing an otolith bathing in endolymph. Otoliths in teleost fish are calcified structures involved in hearing and maintenance of equilibrium (Fay, 1984; Popper and Fay, 1993). Otolith consists of a predominant (>90\%) mineral phase of calcium carbonate in aragonite form (Carlstrom, 1963) incorporated into an organic matrix (OM), which accounts for 0.01 to $10 \%$ of the total weight (Degens et al., 1969; Borelli et al., 2001). The saccular epithelium, containing the largest otolith, is characterized by an asymmetric distribution of ionocytes (Mayer-Gostan et al., 1997; Takagi, 1997) and abundant secretingcells (Pisam et al., 1998; Takagi and Takahashi, 1999). As otoliths are spatially separated from the saccular epithelium, the mechanism of their calcification is an acellular process taking place in the endolymph. Consequently, authors suggested that the specific composition of the endolymph was involved in the otolith calcification process (Romanek and Gauldie, 1996; Payan et al., 1997).

The endolymph is a peculiar medium, with concentrations of $\mathrm{Na}^{+}$and $\mathrm{Cl}^{-}$comparable to those of classical extracellular compartments, but characterized by a high $\mathrm{K}^{+}$concentration, an alkaline $\mathrm{pH}$, and a high $\mathrm{HCO}_{3}{ }^{-}$concentration (Enger, 1964; Kalish, 1991; Payan et al., 1997). Payan et al. (1999) showed that endolymph components (proteins and ionic parameters) displayed a lack of uniformity in their spatial distribution within the saccule. Recently, Borelli et al. (2001) showed that trout endolymph not only contained various proteins but also proteoglycans and collagens that were not uniformly distributed either.

In order to better understand the process of the otolith growth and to clarify which components of endolymph were involved in the calcification process, the approach chosen in the present work was to examine the variations of the endolymph organic composition in conditions known to induce modifications in the otolith growth. Three conditions have been selected: the circadian cycle, the effect of starvation and the effect of stress. During the daynight cycle, Mugiya and Takahashi (1985) showed simultaneous diurnal variations of $\mathrm{pH}$ and of total $\mathrm{CO}_{2}$ concentration in trout plasma and pooled endolymphs. Edeyer et al. (2000) confirmed the variations of total $\mathrm{CO}_{2}$ in turbot proximal and distal endolymphs, and also showed protein variations during the day-night cycle, with a maximum reached during the day. Recently, Borelli et al. (2003b) showed that cyclic variations of $\mathrm{Ca}^{2+}$ and $\mathrm{CO}_{2}$ concentrations induced an increase in aragonite saturation in the proximal endolymph during the night period whereas proteins and collagen were in favor of the matrix formation during the day period. However, the $\mathrm{CaCO}_{3}$ deposit in otolith only took place at the beginning of the day period (Wright et al., 1992). Starvation was shown to induce modifications in otolith microstructure in relation to the event intensity and duration (Pannella, 1980). Payan et al. (1998) showed a relationship between the decrease of $\mathrm{pH}$ and total $\mathrm{CO}_{2}$ concentration in trout pooled endolymph (proximal plus distal), suggesting that ionic parameters were involved in otolith calcification. They also showed that protein concentration remained unchanged in pooled endolymph. A stress induced by exposure to $\mathrm{Cl}_{2}$ gas was recently shown to induce increases in protein and total $\mathrm{CO}_{2}$ concentrations in the proximal endolymph, and a decrease in otolith growth with a discontinuity in the microstructure (check) (Payan et al., 2004).

Although these three conditions have been already partially studied, they were reexamined in the present study to evaluate the variations in the endolymph of two other parameters that could play a major role in the otolith growth: a factor controlling the calcium carbonate crystallization, and proteins that can be considered as precursors of the otolith organic matrix.

The presence of a factor inhibiting the in vitro $\mathrm{CaCO}_{3}$ crystallization was shown in the organic matrix of various calcareous structures : oyster shell (Wheeler et al., 1981), fish otolith (Wright, 1991; Borelli et al. 2001), chicken egg shell (Gautron et al., 1996, 1997), 
coccolith (Okazaki et al., 1998), molluscs and corals (Marin et al., 2000). Among these biominerals, only egg shell and the fish otolith are suitable for analytical study since there is access to the fluids surrounding them (uterine fluid and endolymph respectively). The activity of a factor, that we prefer to call « factor retarding crystallization » (FRC), was found in the endolymph and in the soluble matrix of the otolith of trout and turbot (Borelli et al., 2001). FRC activity per $\mu$ g protein was found 65 and 45 times greater in the otolith than in the endolymph of trout and turbot respectively. Although this factor is not yet known, it has been shown to co-precipitate with proteins in TCA (Borelli et al., 2003a). In order to obtain more information about this factor, we carried out the three following experiments: 1) proximal and distal endolymphs were treated with ethanol or acetone and the FRC recoveries were determined in the different phases of each treatment, 2) endolymph proteins, run on an electrophoresis gel, were electro-eluted and an estimation of the FRC apparent molecular weight was undertaken by measuring the calcification activity contained in each sample and 3) FRC activity was determined in proximal and distal endolymphs under the 3 different environmental conditions.

Takagi and Takahashi (1999) showed the presence of a specific precursor (>94 kDa) of the otolith EDTA-soluble OM detectable in the trout endolymph. Borelli et al. (2003b) showed by western blots, using an antibody raised against the otolith acetic acid-soluble fraction of $\mathrm{OM}$, that some proteins (75 and $65 \mathrm{kDa}$ ) present in the endolymph were precursors of the OM and that they would be incorporated in the otolith. Borelli et al. (2003b) also showed that there was a difference in the amount of OM precursors between night and day endolymph samples. In the present work, protein concentrations in the proximal endolymphs collected from animals adapted to the three different conditions were measured and the respective protein electrophoresis patterns analyzed. Western blots, using the same antibody, were carried out and differences in the labeling intensity observed in the different conditions were discussed with reference to the day-control.

The results taken together will be discussed in relation to otolith growth and microstructure.

\section{Materials and methods}

\subsection{Fish handling}

Turbot (Psetta maxima) of 140 to $320 \mathrm{~g}$ body weights and 1 to 2-year old were reared at IFREMER Brest, and kept in running seawater at $14^{\circ} \mathrm{C}$ for at least 3 weeks before experimentation. They were maintained under a constant photoperiodicity (12h light: 12h dark) and fed once a day.

Trout (Oncorhynchus mykiss) of 220 to 360 g body weights and 12-month old were obtained from a local fish farm (Auribeau-sur-Siagne). They were maintained in running tap water at $17^{\circ} \mathrm{C}$ for at least 3 weeks before experimentation. They were kept under a constant photoperiodicity (12h light: $12 \mathrm{~h}$ dark), the day period starting at $08.00 \mathrm{~h}$. Trouts were fed once a day every morning. The withdrawals were performed in February and March between 11.00 and $15.00 \mathrm{~h}$, except for night study (04.00 and $06.00 \mathrm{~h}$ ).

About 80 trouts were divided at random in four groups. The first group, used for control (day period), was maintained in the conditions described above. The second one was collected during the night period. The third group has been starved for 6-7 weeks prior to experimentation. The fourth group was submitted to stress. For achieving the latter experiments, we deliberately made use of the fact that the Municipal Water Board of Nice told us in advance any change in the water treatment (from ozonization to chlorination). The dissolution of $\mathrm{Cl}_{2}$ gas in water gives hypochlorous acid ( $\mathrm{HOCl}$, actually free chlorine), the sterilizing form of the chlorine (Bass and Heath, 1977). Hypochlorous acid can also be obtained from chloramine-T, widely used as a disinfectant in aquacultural therapeutics (Booth 
and Mc Donald, 1988). Chloramine-T breaks down in water by nucleophilic substitution and releases the hypochlorite ion $\left(\mathrm{OCl}^{-}\right)$that produces hypochlorite acid in presence of $\mathrm{H}^{+}(\mathrm{pKa}=$ 7.5). Fish were not otherwise stressed as the change was carried out by water supply only and according to the Water Board. A final $\mathrm{Cl}_{2}$ concentration of 25 ng. $\mathrm{l}^{-1}$ was reached after 1-2 days and the exposure lasted for 8 days.

\subsection{Collections of endolymph.}

The experiments reported in this paper complied with the Principles of Animal Care of the National Institute of Health (publication $N^{\circ} 86$, revised 1985) and the French laws for experiments on animals (decree $\mathrm{N}^{\circ} 87-848$ ).

Endolymphs were collected as described by Payan et al. (1997) between 11.00 and $15.00 \mathrm{~h}$ (for day period) and between 04.00 and $06.00 \mathrm{~h}$ (for night period). Briefly, after decapitation of the fish, the operative field was washed 3 times with $150 \mathrm{mM} \mathrm{NaCl}$. Then, the saccular epithelium was incised to allow the collection of endolymph as two samples, one from the proximal zone (space between the macula and the otolith) and the other one from the distal zone (space facing the opposite side of the otolith). Samples were stored at $-20{ }^{\circ} \mathrm{C}$ until analysis.

\subsection{Determination of protein concentration}

The protein concentration was measured by colorimetry using Coomassie blue (Bradford Biorad assay kit, Marne-la-Coquette, France) with bovine serum albumin as a standard (0-20 mg..$\left.^{-1}\right)$.

\subsection{Precipitation of proteins}

Ethanol and acetone precipitation techniques were used to separate proteins. Briefly, $50 \mu \mathrm{l}$ of (turbot or trout) endolymph were introduced to $1 \mathrm{ml}$ of ice-cold ethanol or acetone. After $1 \mathrm{~h}$ at $-20^{\circ} \mathrm{C}$, the supernatant and the pellet were separated by centrifugation $(10000 \mathrm{~g}$, 20 min. at $4^{\circ} \mathrm{C}$ ). before being dried with an Eppendorf concentrator $5103\left(30 \mathrm{~min}\right.$. at $40^{\circ} \mathrm{C}$ ). Both fractions were then dissolved in deionized water to measure proteins and FRC activities.

\section{5. "In vitro" calcification assay: measurement of the FRC activity}

The in vitro calcification technique described by Wheeler et al. (1981) was used with some modifications (Borelli et al., 2001): the temperature was controlled $\left(18^{\circ} \mathrm{C}\right)$ and the final volume reduced to $1 \mathrm{ml}$ was maintained under a constant mixing. A mini-electrode (Tacussel, Villeurbane, France) connected to an acquisition data system (Maclab) allowed to record the $\mathrm{pH}$ during $\mathrm{CaCO}_{3}$ precipitation. When $0.5 \mathrm{ml}$ of $\mathrm{CaCl}_{2}(40 \mathrm{mM})$ was added to $0.5 \mathrm{ml}$ of $\mathrm{NaHCO}_{3}\left(40 \mathrm{mM}, \mathrm{pH}\right.$ 8.5), there were a precipitation of $\mathrm{CaCO}_{3}$ and a proton release (following the reaction: $\mathrm{Ca}^{2+}+\mathrm{HCO}_{3}{ }^{-} \rightarrow \mathrm{CaCO}_{3}+\mathrm{H}^{+}$). The time necessary for one unit $\mathrm{pH}$ decrease was measured. In absence of endolymph, the time found was taken as the reference value, the initial $\mathrm{pH}$ of 8.6 being that one of bicarbonate solution alone. The FRC activity was determined by the delay to obtain 1 unit $\mathrm{pH}$ decrease when the endolymph sample was added to the $\mathrm{NaHCO}_{3}$ solution before $\mathrm{CaCl}_{2}$ addition.

\subsection{SDS-PAGE}

SDS-Polyacrylamide gel tris-glycine $12 \%$ was used in reducing conditions with $5 \mu \mathrm{g}$ protein per well, following the method of Laemmli (1970). The $5 \mu \mathrm{g}$ protein deposit corresponded to a fraction of pooled trout proximal endolymph. The gel was run at a constant voltage of $100 \mathrm{~V}$ for $2 \mathrm{~h}$ at $4^{\circ} \mathrm{C}$. Proteins were stained with silver stain plus kit (Biorad, Marne-la-Coquette, France). Standard proteins used were kaleidoscope prestained standards (Sigma, Saint-Quentin Fallavier, France): myosin (205 kDa), galactosidase (116 kDa), albumin (66 kDa), ovalbumin (45 kDa), carbonic anhydrase (29 kDa), trypsin inhibitor (20 $\mathrm{kDa})$, lactalbumin $(14.2 \mathrm{kDa})$ and aprotinin $(6.5 \mathrm{kDa})$. The densitometric profiles were analyzed using software developed by the National Institute of Health (N.I.H 1.57, Research Services Branch). 


\subsection{Electro elution}

Wells (except the one loaded with molecular weight protein markers) were loaded with $20 \mu$ g pooled turbot endolymph $(n=3)$ and submitted to electrophoresis. Then, proteins were removed from the gel using the "gel eluter" (Biorad, Marne-la-Coquette, France) in presence of an acetic acid $(20 \mathrm{mM})$-GABA $(20 \mathrm{mM})$ buffer system. The lane containing the markers was used to position correctly the gel on the apparatus and was then removed from the gel. The gel was eluted at a constant tension of $80 \mathrm{~mA}$ for $20 \mathrm{~min}$. After elution, samples were dialyzed twice against 5-liter of distilled water, overnight at $4^{\circ} \mathrm{C}$ under constant mixing. This dialysis was a necessary step to eliminate buffer and thus to allow the in vitro calcification assay to be run. Four electro elutions were run.

\subsection{Western blot}

Electrophoresis gels from pooled trout proximal endolymph were transferred onto a nitrocellulose membrane (Sigma, $0.45 \mu \mathrm{m}$ pore size) and the immunoblotting was performed following the method of Towbin et al. (1979). The membrane was first incubated with 5\% milk for $1 \mathrm{~h}$ to block the non-specific binding. Then, the membrane was incubated (overnight at $\left.4^{\circ} \mathrm{C}\right)$ with a rabbit antiserum $(1 / 2000$ dilution) raised against the $\mathrm{OM}$ of trout otolith (Borelli et al., 2003b). After rinsing, the membrane was incubated with peroxydaseconjugated goat anti-rabbit globulin (Biorad). Localization was visualized with the ECL technique (Perkin Elmer, Courtaboeuf, France).

The polyclonal antibody was obtained as described by (Borelli et al., 2003b). Briefly, otoliths were washed with $\mathrm{NaOH}$, rinsed with deionised water and wiped before grounding. Acid acetic-soluble fraction was ultra filtered, lyophilized and freeze-dried OM was sent to Eurogentec (Angers, France) and used to generate polyclonal antibody in the rabbit. The polyclonal antibody was shown to react with the soluble fraction of trout otolith organic matrix (dot blot) and to label the trout otolith decalcified by etching with $0.1 \%$ acetic acid (data not shown).

\subsection{Statistical analysis}

Results were expressed as means \pm standard error (n specified) and were analyzed statistically with the Statview software (Berkeley, USA). Comparison of the means was made by a one-way ANOVA. Differences were considered significant at $\mathrm{P}<0.05$.

\section{Results}

\subsection{Chemical characterization of FRC in the endolymph of turbot and trout}

Proteins of turbot or trout endolymphs were precipitated by ice-cold ethanol treatment. The FRC activity was principally recovered in the pellet $(99 \pm 6 \%$ in turbot, $n=6 ; 70-80 \%$ in trout), which contained $97 \% \pm 10 \%(n=6)$ of the total proteins. However, the total activity recovered (pellet plus supernatant) represents $60 \%$ of the initial one in both turbot and trout. When endolymph proteins were precipitated by ice-cold acetone treatment, the activity was principally recovered in the pellet ( $90 \pm 5 \%$ in turbot, $n=6 ; 70-90 \%$ in trout), and the total activity (pellet plus supernatant) recovered was within the range of the initial activity for both turbot and trout. After ice-cold acetone treatment, proteins were divided between pellet ( $80 \pm$ $5 \%, \mathrm{n}=6)$ and supernatant $(20 \pm 2 \%, \mathrm{n}=6)$.

\subsection{Molecular weight determination of FRC in turbot endolymph}

In a preliminary experiment, endolymph sample was eluted in four fractions. The highest FRC activity was recovered in the fraction containing proteins with molecular weights below $66 \mathrm{kDa}$ (not shown).

In the present study, protein concentration and FRC activity in the initial endolymph sample were measured before separation by electrophoresis. Then, the proteins were electro eluted from the gel in several fractions and the FRC activity contained in each fraction was measured (Figure 1 presents an example of that recovery). The fraction with the highest 
specific FRC activity corresponded to proteins having molecular weights around $20 \mathrm{kDa}$. The specific activity contained in this fraction was higher (2-6 times) than those obtained in the other fractions. It should be noticed that the sum of the activities recovered from all fractions was 2.5 fold higher than the initial activity obtained in the endolymph. The fractions with the highest specific activity represented a FRC enrichment by a factor ranging between 50 and 80 of the initial endolymph sample (3.8 second. $\mu \mathrm{g}^{-1}$ ).

\subsection{Composition of trout endolymph on day experiments (control)}

The protein concentrations in the proximal samples were significantly higher (4.5 times) than in the distal ones (Table 1, day). The spatial distribution of FRC in the proximal and distal endolymphs displayed also a lack of uniformity (Table 1, day). The FRC activity (sec. $\mathrm{l}^{-1}$ ) expressed in the proximal zone was significantly higher (3.5 fold) than that found in the distal one. Gel electrophoresis of proximal endolymph (Figure 2, day) displayed a complex protein pattern covering a large range of molecular weights with major bands (around or greater than $200 \mathrm{kDa}$, a triplet around $80 \mathrm{kDa}$, one band around $28 \mathrm{kDa}$ and one around $7.6 \mathrm{kDa}$ ) and several minor bands. Analysis of the western blot (Figure 3, day), showed that a labeling was observed for protein(s) of 60-80 kDa.

\subsection{Composition of trout endolymph during night experiments}

The protein concentrations in the proximal endolymphs were 3.5 fold higher than in the distal ones (Table 1, night). The proximo-distal gradient was maintained but reduced by comparison to the day period. The decrease was only due to the significant $(\mathrm{p}<0.0069)$ decrease of protein concentration in the proximal endolymph whereas the protein concentration remained unchanged in the distal one during the night period. The FRC activity (sec. $\mu l^{-1}$ ) in the endolymph displayed a lack of uniformity (Table 1, night) with the activity significantly higher in the proximal zone (nearly 4 fold) than in the distal one. There was no significant difference between the activities measured during the day and night periods. Analysis of gel electrophoresis (Figure 2, night) showed that the night proteic profile of the proximal endolymph was globally similar to the day one: the major bands were present but several minor bands were denser during the night period. Analysis of the western blot (Figure 3 , night) revealed a band for protein(s) of molecular weights similar to, but half concentrated than those observed in the day sample

\subsection{Composition of trout endolymph after starvation}

After 6-7 weeks of starvation, the spatial distribution of protein concentration in the proximal and distal endolymphs remained unchanged in comparison to that measured in control (Table 1, starvation). The FRC activity (sec. $\mathrm{ll}^{-1}$ ) expressed in the endolymph still presented a lack of uniformity (proximal/distal ratio $=5.8$ ). While the activity expressed in the proximal endolymph samples was significantly reduced $(\mathrm{p}<0.0001)$ after starvation by comparison to the control period, it was not significantly modified in the distal endolymph ( $\mathrm{p}$ $<0.06$ ). After starvation, the proximal endolymph protein pattern was globally similar to the control one (Figure 2, starvation) with the major bands still visible, although that around 7.6 $\mathrm{kDa}$ was less dense than in control. There were also variations in the amounts of many minor bands. After starvation, the labeling of proximal endolymph by the antibody was observed for molecule(s) of molecular weights similar to those observed in the control (60-80 kDa). The labeling intensity was about 3 fold higher than in control (Figure 3, starvation).

\subsection{Composition of trout endolymph after $\mathrm{Cl}_{2}$-stress condition}

Under $\mathrm{Cl}_{2}$-stress condition, the proximo-distal difference in protein concentration was increased (Table 1, stress). While the protein concentration was 1.5 fold higher in proximal endolymph of stressed fish than in control, it did not change in the distal one. The FRC activity (sec. $\mathrm{l}^{-1}$ ) in the proximal endolymph was 2.3 fold lower than in control. The endolymph protein pattern was globally similar to the control one (Figure 2, stress), with the major bands still visible. It should be noticed that molecules with high molecular weights 
were denser than in control. There were also increases in the amount of many minor bands. After $\mathrm{Cl}_{2}$-stress, the labeling of the proximal endolymph by the antibody was observed for molecule(s) of apparent molecular weights similar to, but 2 fold denser than those of control (60-80 kDa) (Figure 3, stress).

\section{Discussion}

\subsection{Relationship between protein concentration in endolymph and otolith growth}

The present data confirm the significant difference between the protein concentrations in control trout proximal and distal endolymphs already observed (Payan et al., 1999; Edeyer et al., 2000; Borelli et al., 2003b). This difference has been proposed to result from the asymmetric distribution of the secreting-cells on the saccular epithelium (Mayer-Gostan et al., 1997, Takagi, 1997). The otolith proximal face (convex) displaying a growth greater than that in the distal one, the present results reinforce the hypothesis suggesting that the organic gradient in the endolymph could act as a driving force to organize the spatial orientation of the otolith growth along determined axes (Borelli et al., 2001).

Variations of protein concentration in proximal endolymph during the day-night cycle had already been described in trout (Borelli et al., 2003b) and in turbot (Edeyer et al., 2000), showing a maximal concentration during the day period. Our data are also in accordance with Gauldie and Nelson's observations (1988). These authors described a daily variation of the number of granule secretion in the secreting-cells of the saccular epithelium.

In the present work, the protein concentration measured in the proximal and distal endolymphs of starving fish is not significantly different from those of control. This was already shown by Payan et al. (1998) on pooled endolymphs. Campana (1983) showed that starvation resulted in a decrease of the otolith increments that matched the slow down of the somatic growth.

$\mathrm{A} \mathrm{Cl}_{2}$-stress similar to that carried out in the present work has been shown to increase significantly the protein concentration in the endolymph and to induce the formation of check on otolith microstructure (Payan et al., 2004). It could be tempting to link the increase of protein concentration in endolymph with the appearance of a check in the otolith. However, a simple relationship between the protein concentration in the endolymph and the amount of matrix deposit on the otolith may be meaningless as only $0.017 \%$ of endolymph proteins were incorporated daily (Borelli et al., 2001).

The electrophoretic patterns of endolymph proteins were globally similar for the major bands whatever the experimental conditions (day, night, starvation or stress), but revealed variations of many minor bands of unknown molecules. The interpretation of these differences is not yet possible in absence of specific tools allowing characterization of the proteins and showing their incorporation in the otolith matrix.

\subsection{The organic matrix precursor variations in endolymph}

An essential role has been ascribed to the endolymph since it contains the precursor elements of the otolith $\mathrm{OM}$ and is the only transit way towards the otolith. Takagi and Takahashi (1999) showed the presence of a specific precursor ( $>94 \mathrm{kDa}$ ) of the otolith EDTA-soluble OM detectable in the trout endolymph. The antibody used in the present work has been raised against the otolith acetic acid-soluble $\mathrm{OM}$ of rainbow trout and has been shown to detect the expression of 2 precursors (75 and $65 \mathrm{kDa}$ ) in the endolymph (Borelli et al., 2003b). In the present study, the two proteins cannot be distinguished probably because of the intensity of major band response. The NIH analysis of western blot confirmed the variations of precursor concentration in the endolymph during the day-night cycle with a maximum during the day period, already observed by Borelli et al. (2003b).

After $\mathrm{Cl}_{2}$ stress, we observed an increase of precursors in the endolymph. The stress induced by chlorine exposure, as carried out in the present work, has been previously shown 
to induce the formation of a check on otolith microstructure (Payan et al., 2004). Induction of biological tags in otoliths was also observed after stress like temperature, UV-B radiation, salinity (Berghahn and Karakiri, 1990; Elsdon and Gillanders, 2002). We propose that the increase of precursor(s) observed after $\mathrm{Cl}_{2}$ stress could be linked to the increase of the hyaline microstructure which characterized the check.

There were many studies showing that the otolith growth reflected the somatic growth rates (Molony and Choat, 1990) and that they were reduced after starvation (Molony, 1996). Berghahn and Karakiri (1990) also observed that starvation in juvenile Pleuronectes platessa induced the formation of small biological tags. In the present work, the increase of the precursors observed after starvation was unexpected. However, the trout used in the present work were one year-old, they were grown up in farm and thus they could have succeeded in maintaining protein (and precursor) synthesis using the organism reserves. In the present study, the otolith microstructure has not been studied, so we do not know whether the increase of the precursors observed could be linked to biological tags.

The molecular weight of the precursors detected by western blot in the present study excludes the molecules already described such as otolin (PM 100k Da) characterized in Oncorhynchus keta (Murayama et al., 2002) and Oncorhynchus mykiss (Murayama et al., 2004), and OMP-1 (PM $55 \mathrm{k} \mathrm{Da}$ ) found in the rainbow trout (Murayama et al., 2000, 2004). Recently, Takagi et al. (2005) observed a day-night fluctuation in mRNA expression of otolin-1 suggesting that fluctuations in otolin-1 (an abundant protein of otolith matrix) synthesis might contribute to the daily otolith increment. The daily variations of the precursor, revealed by our antibody, suggest that it may also participate to the daily otolith increment. Preliminary experiment carried out with otolith treated with the OM-immunoserum showed clearly that our antibody recognizes organic matrix proteins. The labeling displayed stria that could look like growth rings (data not shown). A third molecule shown to be present in the otolith and also sequenced was the Starmaker (Söllner et al., 2003) with a molecular weight of $66 \mathrm{kDa}$.

\subsection{Role of the FRC}

The otolith calcification is an acellular process that takes place at the endolymphotolith interface. It has been accepted that the organic matrix, mainly composed of proteins such as glycoproteins, collagens, proteoglycans and $\mathrm{Ca}^{2+}$-binding proteins, was essential in the calcification process (Morales-Nin, 1987; Wright, 1991; Asano and Mugiya, 1993; Sasagawa and Mugiya, 1996, Borelli et al., 2001; Murayama et al., 2002, Söllner et al. 2003). The organic matrix was considered to play a major role in different steps such as nucleation, orientation, inhibition, crystal nature and regulation (Wheeler et al., 1981, 1988; Belcher et al., 1996; Falini et al., 1996).

The FRC in vitro activities found in trout and turbot endolymphs (Borelli et al., 2001) were also found in other peri-cristallin fluids involved in calcification such as cephalopod endolymph (Morris, 1991) and chicken uterine fluid (Gautron et al., 1997). The ubiquitous presence of such an activity in the course of evolution suggested that FRC could play a key role in the biological calcification process. In the present study, FRC activities measured in proximal and distal endolymphs are within the range of those found in pooled trout endolymphs (Borelli et al., 2001). It is noticeable that, whatever the condition, the activities measured in the proximal zones are higher than those in the distal ones. FRC activities from proximal and distal endolymphs remained unchanged during the circadian cycle, suggesting that the FRC does not directly control the cyclic process of otolith calcification. After starvation and $\mathrm{Cl}_{2}$ stress, FRC activities from proximal endophymph are significanly reduced (by $70 \%$ and $100 \%$, respectively). In the case of stress, the remaining activity is not significantly different from the nonspecific inhibition observed in the presence of BSA (Borelli et al., 2001). If we consider that calcification is inhibited or delayed by FRC, the 
present results are conflicting with what is known concerning otolith growth and crystallization: 1) the otolith growth is greater on its proximal side than on its distal one, and 2) the reduction of otolith growth rate after stress or starvation mainly results from a decrease in the $\mathrm{CaCO}_{3}$ deposition rate as observed in rainbow trout (Mugiya and Oka, 1991). However, it is admitted that inhibition and nucleation have common attributes and that inhibition will occur when the proteins are in solution whereas nucleation will occur when proteins were adsorbed onto a rigid substrate (Wheeler and Sikes, 1984; Addadi and Weiner, 1985).

We propose that the level of the FRC in the endolymph could be an indicator of the thickness of the aragonite deposit on the otolith and that this could explain the decrease of the otolith growth observed after starvation or stress. It should be noted that the FRC activities do not vary in parallel with the variations of total protein concentrations in the endolymph, suggesting that protein synthesis and/or secretions from the saccular epithelium could be specifically modified depending on the conditions.

In the present study carried out on turbot and trout endolymphs, chemical characteristics (after ethanol or acetone precipitation) of the FRC suggest the presence of a proteic molecule as proposed by Borelli et al. (2003a) using TCA precipitation or methanol/chloroform phase separation on turbot endolymph. However the sum of activities measured after the present treatments was not greater than the initial activity in contrast to what was previously found after TCA precipitation or methanol/chloroform phase separation (Borelli et al., 2003a). In contrast, electro elution of gel electrophoresis brought an enhancement of the total activity of the FRC. As the biochemical nature and the primary structure of the molecules present in the endolymph are not identified yet, it is difficult to provide an explanation for these observations. Discrimination based on electrophoresis elution suggests that the molecules found in the turbot otolith endolymph fractions exhibiting the greatest FRC activities behave like proteins with molecular weights around $20 \mathrm{kDa}$. However, if the proteins involved are highly anionic, an accurate measurement of their molecular weights will be difficult to obtain because this type of proteins does not bind the stains generally used to visualize proteins in gel electrophoresis. Our approach could be considered as a preliminary step to obtain a specific protein-enriched fraction in order to characterize these molecules better and to determine their sequences. To our knowledge, only one molecule, the Starmaker, has been clearly demonstrated to promote aragonite calcification in the otolith (Söllner et al., 2003), but its behavior in the in vitro assay is not known. In the present work, the molecular weight of the FRC (ranging around $20 \mathrm{kDa}$ ) is different from that of Starmaker.

The present study allowed us to show variations of endolymphatic proteins under environmental conditions known to affect otolith growth. The variations of the OM precursors (60-80 kDa) observed in proximal endolymph could be related to the organic deposit on the otolith during the day period (in circadian cycle), and could be linked to tags and checks observed in otolith after starvation or stress. In contrast, the FRC (ca $20 \mathrm{kDa}$ ) activity in the proximal endolymph, which decreases after starvation or stress, suggests that this factor plays a key role in the intensity of aragonite deposit that prevails for the otolith growth. Further step should be to biochemically characterize the nature and structure of these precursors in order to specify their exact role (s) in the otolith growth.

\section{Acknowledgements}

This study was supported by IFREMER. We wish to thank Sylvie Tambutté, Eric Tambutté, Sandrine Puverel and Séverine Lotto (Centre Scientifique de Monaco) for preliminary experiments leading to the development of the antibody used in the present work and immunolabeling of the otolith. 


\section{References}

Addadi, I., Weiner, S. 1985. Interactions between acidic proteins and crystals: stereochemical requirements in biomineralization. Proc. Natl. Acad. Sci. 82, 4110-4114.

Asano, M., Mugiya, Y. 1993. Biochemical and calcium-binding properties of water-soluble proteins isolated from otolith of the Tilapia, Oreochromis niloticus. Comp. Biochem. Physiol. 104B, 201-205.

Bass, M.L., Heath, A.G. 1977. Cardiovascular and respiratory changes in rainbow trout (Salmo gairdneri) exposed intermittently to chlorine. Water Research 11, 497-502.

Belcher, A.M., Wu, X.H., Christensen, R.J., Hansma, P.K., Stuky, G.D., Morse, D.E. 1996. Control of crystal switching and orientation by soluble mollusc-shell proteins. Nature. 381, 56-58.

Berghahm, R., Karakiri, M. 1990. Experimental induction of biological tags in otoliths of 0group plaice Pleuronectes platessa by starvation, temperature, and UV-B radiation. Mar. Ecol. Prog. Ser. 67, 227-233.

Booth, N.H., Mc Donald, L.E. 1988. Veterinary Pharmacology and Therapeutics, $6^{\text {th }}$ ed. Iowa State University Press, Ames. Iowa, pp. 774-777.

Borelli, G., Mayer-Gostan N., De Pontual, H., Bøuf, G., Payan, P. 2001. Biochemical relationships between endolymph and otolith matrix in the trout (Oncorhynchus mykiss) and the turbot (Psetta maxima). Calcified Tissue Int. 69, 356-364.

Borelli, G., Mayer-Gostan, N., Merle, PL., De Pontual, H., Bœuf, G., Allemand, D., Payan, P. 2003a. Composition of biomineral organic matrices with special emphasis on turbot (Psetta maxima) otolith and endolymph. Calcified. Tissue Int. 72, 717-725

Borelli, G., Guibbolini M.E., Mayer-Gostan, N., Priouzeau, F., De Pontual, H., Allemand, D., Puverel, S., Tambutté, E., Payan, P. 2003b. Daily variations of endolymph composition: relationship with otolith calcification process in trout. J. Exp. Biol. 206, 2685-2892.

Campana, S.E. 1983. Calcium deposition and otolith check formation during periods of stress in coho salmon Oncorhynchus kisutch. Comp. Biochem. Physiol. 75A, 215-220.

Carlstom, D. 1963. A crystallographic study of vertebrate otoliths. Biol. Bull. 125, 441-463

Degens, E.T., Deuser, W.G., Haedrich, R.L. 1969. Molecular structure and composition of fish otoliths. Int. J. Life Oceans Coastal Waters. 2,105-113.

Edeyer, A., de Pontual, H., Payan, P., Troadec, H., Severe, A., Mayer-Gostan, N. 2000. Daily variations of the saccular endolymph and plasma compositions in the turbot Psetta maxima: relationship with the diurnal rhythm in otolith formation. Mar. Ecol. Prog. Ser. 192, 287-294.

Elsdon, T.S., Gillanders, B.M. 2002. Interactive effects of temperature and salinity on otolith chemistry: challenges for determining environmental histories of fish. Can. J. Fish. Aquat. Sci. 59, 1796-1808.

Enger, P.R.1964. Ionic composition of the cranial and labyrinth fluids and saccular D.C. potentials in fish. Comp. Biochem. Physiol. 11, 131-137.

Falini, G., Albeck, S., Weiner, S., Addadi, L. 1996. Control of aragonite or calcite polymorphism by mollusk shell macromolecules. Science. 271, 67-69.

Fay, R.R. 1984. The Goldfish Ear codes the axis of acoustic particle motion in three dimensions. Science. 225, 951-953.

Gauldie R.W., Nelson, D.G.A. 1988. Aragonite twinning and neuroprotein secretion are the cause of daily growth rings in fish otoliths. Comp. Biochem. Physiol. 90A, 501-509.

Gautron, J., Bain, M., Solomon, S., Nys, Y. 1996. Soluble matrix of hen's eggshell extracts changes in vitro the rate of calcium carbonate precipitation and crystal morphology. Br. Poult. Sci. 37, 853-866.

Gautron, J., Hincke, M.T., Nys, Y. 1997. Precursor matrix proteins in the uterine fluid change with stages of eggshell formation in hens. Connect. Tissue Res. 36, 195-210 
Kalish, J.M. 1991. Determinants of otolith chemistry: seasonal variation in the composition of blood plasma, endolymph and otoliths of bearded rock cod, Pseudophycis barbatus. Mar. Ecol. Prog. Ser. 74,137-159.

Laemmli, U.K. 1970. Cleavage of structural proteins during the assembly of the head of bacteriophage T4. Nature. 227, 680-685.

Marin, F., Corstjens, P., de Gaulejac, B. de Vrind-De-Jong, E., Westbrœk, P. 2000. Mucins and molluscan calcification. J. Biol. Chem. 275, 20667-20675.

Mayer-Gostan, N., Kossmann, H., Watrin, A., Payan, P., Bœuf, G. 1997. Distribution of ionocytes in the saccular epithelium of the inner ear of two teleosts (Oncorhynchus mykiss and Scophthalmus maximus). Cell Tissue Res. 289, 53-61.

Molony, B.W., Choat, J.H. 1990. Otolith increment widths and somatic growth rate: the presence of a time lag. J. Fish Biol. 37, 541-551.

Molony, B.W. 1996. Episodes of starvation are recorded in the otoliths of juvenile (Ambassis vachelli Chandidae), a tropical estuarine fish. Mar. Biol. 125, 439-446.

Morales-Nin, B. 1987. Ultrastructure of the organic and inorganic constituents of the otoliths of the sea bass. In: Summerfelt, R.C., Hall, G.E. (Eds.), The age and growth of fish. Iowa State University Press, Ames, Iowa, pp. 331-344.

Morris, C.C. 1991. Statocyst fluid composition and its effects on calcium carbonate precipitation in the squid Alloteuthis subulata; towards a model for biomineralization. Bull. Mar. Sci. 49, 379-388.

Mugiya, Y., Takahashi, T. 1985. Chemical properties of the saccular endolymph in the rainbow trout, Salmo gairdneri. Bull. Faculty Fish. Hokkaido University 36, 57-63.

Mugiya, Y., Oka, H. 1991. Chemical relationship between otolith and somatic growth in the Rainbow trout Onchorhynchus mykiss: consequence of starvation, resumed feeding, and diel variations. Fish Bull. 89, 239-245.

Murayama, E., Okuno, A., Ohira, T., Takagi, Y., Nagasawa, H. 2000. Molecular cloning and expression of an otolith matrix protein cDNA from the rainbow trout, Oncorhynchus mykiss. Comp. Biochem. Physiol. 126B, 511-520.

Murayama, E., Takagi, Y., Ohira, T., Davis, J.G., Greene, M.I., Nagasawa, H. 2002. Fish otolith contains a unique structural protein, otolin-1. Eur. J. Biochem. 269, 688-96.

Murayama, E., Takagi, Y., Nagasawa, H. 2004. Immunohistochemical localization of two otolith matrix proteins in the otolith and inner ear of the rainbow trout, Oncorhynchus mykiss: comparative aspects between the adult inner ear and embryonic otocysts. Histochem. Cell. Biol. 121, 155-166.

Okazaki, M., Sato, T., Mutho, N., Wada, N., Umegaki, T. 1998. Calcified scales (coccoliths) of pleurochrysis carterae (Haptophyta): structure, crystallography, and acid polysaccharides. J. Mar. Biotechnol. 6, 16-21.

Pannella, G. 1980. Growth pattern in fish sagittae. In: Rhoads, D.C., Lutz, R.A (Eds.), Skeletal growth of aquatic organisms: biological records of environmental change. Plenum press, New York and London, pp. 519-560.

Payan, P., Kossman, H., Watrin, A., Mayer-Gostan, N., Boeuf, G. 1997. Ionic composition of endolymph in teleosts: origin and importance of endolymph alkalinity. J. Exp. Biol. 200, 1905-1912.

Payan, P., Borelli, G., Boeuf, G., Mayer-Gostan, N. 1998. Relationship between otolith and somatic growth: consequence of starvation on acid-base balance in plasma and endolymph in the rainbow trout Oncorhynchus mykiss. Fish Physiol. Biochem. 19, 35-41.

Payan, P., Edeyer, A., De Pontual, H., Borelli, G., Boeuf, G., Mayer-Gostan, N. 1999. Heterogeneity of endolymph and otolith chemistry of inner ear in teleost fish. Am. J. Physiol. 46, R123-131. 
Payan, P., De Pontual, H., Edeyer, A., Borelli, G., Bœuf, G., Mayer-Gostan, N. 2004. Effects of stress on plasma homeostasis, endolymph chemistry and check formation during otolith growth in trout (Oncorhynchus mykiss). Can. J. Fish. Aquat. Sci. 61, 1247-1255

Pisam M., Payan P., Le Moal C., Edeyer A., Boeuf G., Mayer-Gostan N. 1998. Ultrastructural study of the saccular epithelium of the inner ear of two teleosts (Oncorhynchus mykiss and Psetta maxima). Cell Tissue Res. 294, 261-270.

Popper, A.N., Fay, RR. 1993. Sound detection and processing by fish: critical review and major research questions. Brain Behav. Evol. 41, 14-38.

Romanek, C.S., Gauldie, R.W. 1996. A predictive model of otolith growth in fish based on the chemistry of the endolymph. Comp. Biochem. Physiol. 114A, 71-79.

Sasagawa, T., Mugiya, Y. 1996. Biochemical properties of water-soluble otolith proteins and the immunobiochemical detection of the proteins in serum and various tissues in the tilapia, Oreochromis niloticus. Fisheries Sci. 62, 970-976.

Söllner, C., Burghammer, M., Busch-Nentwich, E., Berger, J., Schwarz, H., Riekel, C., Nicolson, E. 2003. Control of crystal size and lattice formation by Starmaker in otolith biomineralization. Science. 302, 282-286

Takagi, Y. 1997. Meshwork arrangement of mitochondria-rich, $\mathrm{Na}^{+}, \mathrm{K}^{+}$-ATPase-rich cell in the saccular epithelium of rainbow trout (Oncorhynchus mykiss) inner ear. Anat. Rec. 248, 483-489.

Takagi, Y., Takahashi, A. 1999. Characterization of otolith soluble-matrix producing cells in the saccular epithelium of rainbow trout (Oncorhynchus mykiss) inner ear. Anat. Rec. 254, 322-329.

Takagi, Y., Toshe, H., Murayama, E., Ohira, T., Nagasawa, H. 2005. Diel changes in endolymph aragonite saturation rate and mRNA expression of otolith matrix proteins in the trout otolith organ. Mar. Ecol. Prog. Ser.. 294, 249-256.

Towbin, H,. Staehelin, T., Gordon, J. 1979. Electrophoretic transfer of proteins from polyacrylamide gels to nitrocellulose sheets: procedure and some applications. Proc. Natl. Acad. Sci. U.S.A. 76, 4350-4354.

Wheeler, A.P., George, J.W., Evans, C.A. 1981. Control of carbonate nucleation and crystal growth by soluble matrix of oyster shell. Science. 212, 1392-1398.

Wheeler, A.P., Rusenko, K.W., Swift, D.M., Sikes, C.S. 1988. Regulation of in vitro and in vivo $\mathrm{CaCO}_{3}$ crystallization by fractions of oyster shell organic matrix. Mar. Biol. 98, 7180.

Wheeler, A. P., Sikes, C. S. 1984. Regulation of carbonate calcification by organic matrix. Am. Zool. 24, 933-944.

Wright, P. J. 1991. Calcium binding by soluble matrix of the otoliths of atlantic salmon, Salmo salar L. J. Fish Biol. 38, 625-627.

Wright, P.J., Talbot, C., Thorpe, J.E. 1992. Otolith calcification in Atlantic salmon parr (Salmo salar L.) and its relation to photoperiod and calcium metabolism. J. Fish Biol. 40, 779-790. 
Table 1. Comparison between protein concentrations and in vitro calcification parameters (FRC) in proximal and distal trout endolymphs measured during the day (control situation) or night periods and after starvation or stress.

\begin{tabular}{|c|c|c|c|c|c|c|}
\hline $\begin{array}{c}\text { Experimental } \\
\text { conditions }\end{array}$ & \multicolumn{3}{|c|}{ Protein (g/l) } & \multicolumn{3}{c|}{$\begin{array}{c}\text { FRC Activity } \\
(\mathrm{sec} / \mu \mathrm{l} \text { endolymph) }\end{array}$} \\
\hline & Proximal & Distal & $P$ & Proximal & Distal & $\begin{array}{c}P \\
\text { Values }\end{array}$ \\
\hline $\begin{array}{c}\text { Day } \\
(\text { control })\end{array}$ & $\begin{array}{c}15.14 \pm 0.95 \\
(\mathrm{n}=9)\end{array}$ & $\begin{array}{c}3.39 \pm 1.18 \\
(\mathrm{n}=9)\end{array}$ & 0.0001 & $\begin{array}{c}69.7 \pm 4.2 \\
(\mathrm{n}=9)\end{array}$ & $\begin{array}{c}19.4 \pm 5.8 \\
(\mathrm{n}=9)\end{array}$ & 0.0001 \\
\hline
\end{tabular}

\begin{tabular}{|c|c|c|c|c|c|c|}
\hline Night & $\begin{array}{c}11.80 \pm 0.58 \\
(\mathrm{n}=10)\end{array}$ & $\begin{array}{c}3.33 \pm 1.1 \\
(\mathrm{n}=8)\end{array}$ & 0.0001 & $\begin{array}{c}74.2 \pm 5.2 \\
(\mathrm{n}=9)\end{array}$ & $\begin{array}{c}18.6 \pm 5.3 \\
(\mathrm{n}=9)\end{array}$ & 0.0001 \\
\hline $\mathrm{P}$ & 0.0069 & $\mathrm{NS}$ & & $\mathrm{NS}$ & $\mathrm{NS}$ & \\
\hline
\end{tabular}

\begin{tabular}{|c|c|c|c|c|c|c|}
\hline Starvation & $\begin{array}{c}15.06 \pm 1.05 \\
(\mathrm{n}=9)\end{array}$ & $\begin{array}{c}1.2 \pm 0.47 \\
(\mathrm{n}=9)\end{array}$ & 0.0001 & $\begin{array}{c}41.2 \pm 2.5 \\
(\mathrm{n}=9)\end{array}$ & $\begin{array}{c}7 \pm 2.1 \\
(\mathrm{n}=9)\end{array}$ & 0.0001 \\
\hline $\mathrm{P}$ & $\mathrm{NS}$ & $\mathrm{NS}$ & & 0.0001 & $\mathrm{NS}$ & \\
\hline
\end{tabular}

\begin{tabular}{|c|c|c|c|c|c|c|}
\hline Stress & $\begin{array}{c}22.43 \pm 0.95 \\
(\mathrm{n}=8)\end{array}$ & $\begin{array}{c}3.51 \pm 0.84 \\
(\mathrm{n}=9)\end{array}$ & 0.0001 & $\begin{array}{c}29.2 \pm 2.2 \\
(\mathrm{n}=8)\end{array}$ & & \\
\hline $\mathrm{P}$ & 0.0002 & $\mathrm{NS}$ & & 0.0001 & & \\
\hline
\end{tabular}

Values are means \pm SE, with number of measurements in brackets. Significance of comparison $(P)$ between data obtained from proximal and distal endolymphs are given on the same line whereas the significance of comparison (P) between experimental groups and control are given on the same column. NS: non significant. 


\section{Figure 1.}

Example of results obtained after electro-elution of pooled turbot endolymph proteins submitted to electrophoresis.

A) FRC activity recovered in the different fractions (expressed as sec.fraction ${ }^{-1}$ ), B) Protein amount per fraction (expressed as $\mu \mathrm{g}$ protein.fraction ${ }^{-1}$ ), and C) Specific FRC activity recovered in the different fractions (expressed as sec. $\mathrm{ug}^{-1}$ of protein). The arrows indicate the position of the molecular weight markers. 

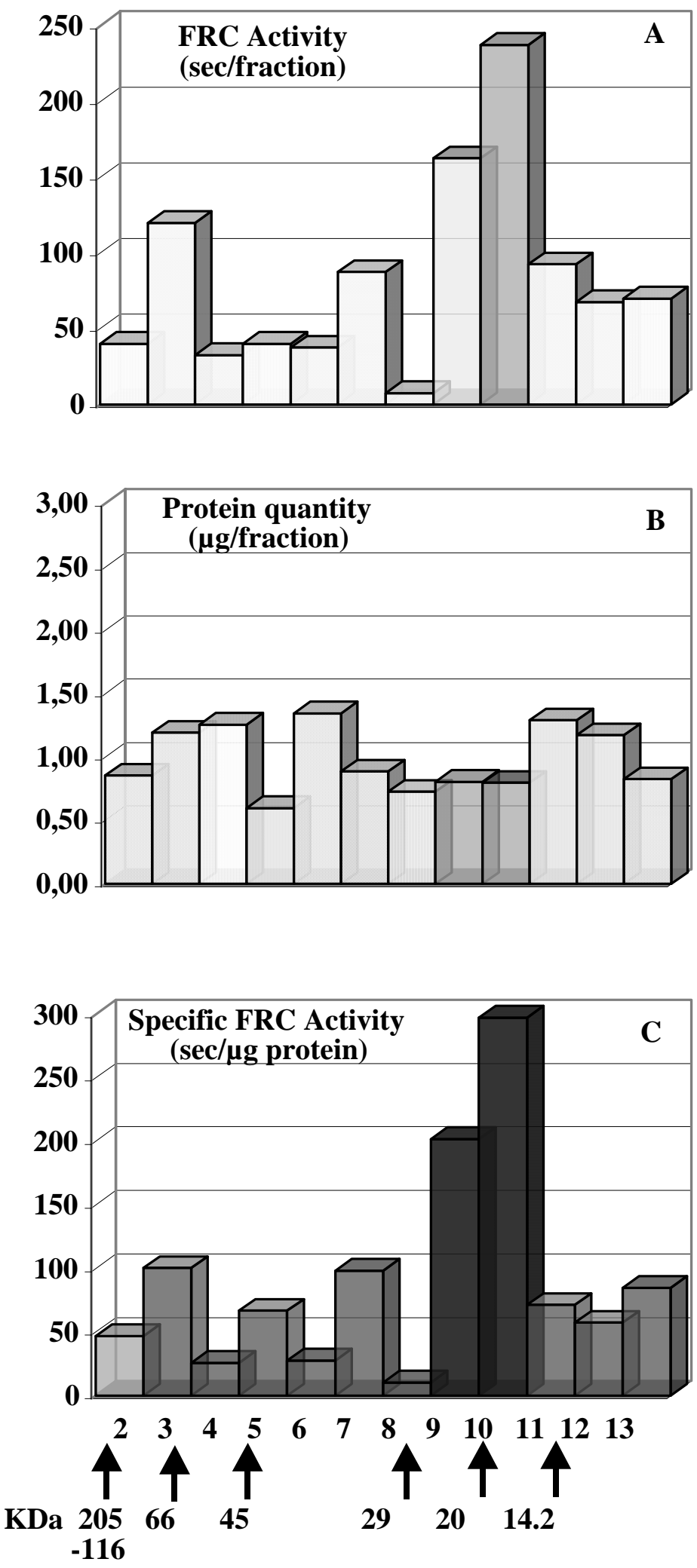

Figure 1 


\section{Figure 2.}

Comparison between electrophoresis patterns of pooled proximal endolymphs collected from trout in different experimental conditions (day, night, fast and stress).

SDS-Polyacrylamide gel tris-glycine $12 \%$ was used in reducing conditions with $5 \mu$ g protein per well. Apparent molecular weight markers $(\mathrm{kDa})$ are indicated on left side. Electrophoresis patterns stained with silver stain plus kit are represented in center. Analysis by densitometry (see Materials and Methods) of the gels is displayed on the right side of the figure. Dark traces represent the level of density of the proteins in night, fast and stress samples whereas the grey trace serves for comparison and represents the day sample (control).

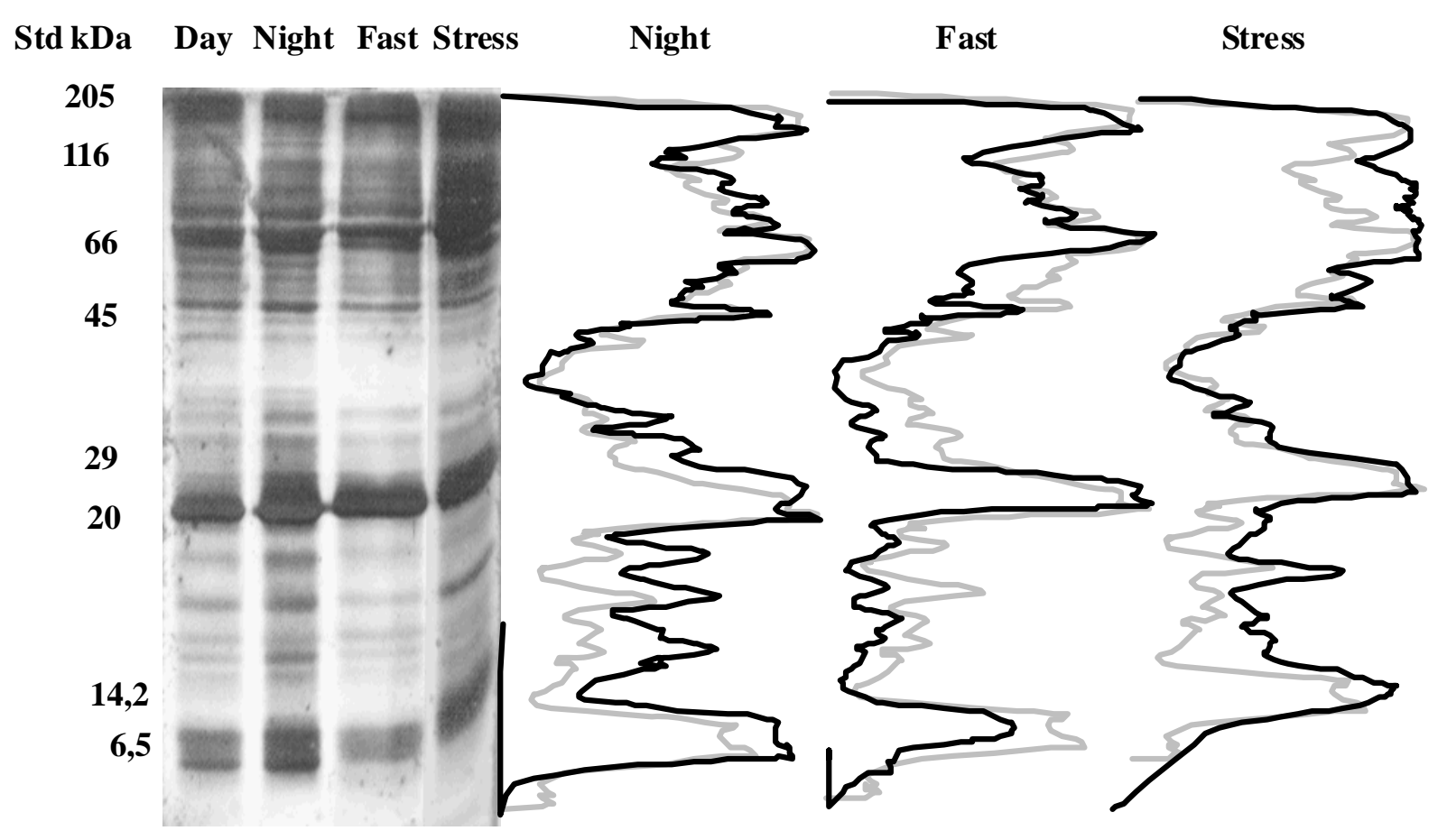




\section{Figure 3}

Comparison between western blots of pooled proximal trout endolymphs showing variations in the amount of otolith organic matrix precursors.

Horseradish peroxydase-labeled western blots are presented on top of the figure. Molecular weight markers are indicated on left. Densitometric analysis of the western blot labeling is given underneath. The dark traces represent the labeling of samples in the experimental conditions (night, starvation and stress) and the grey trace represents that in control (day).
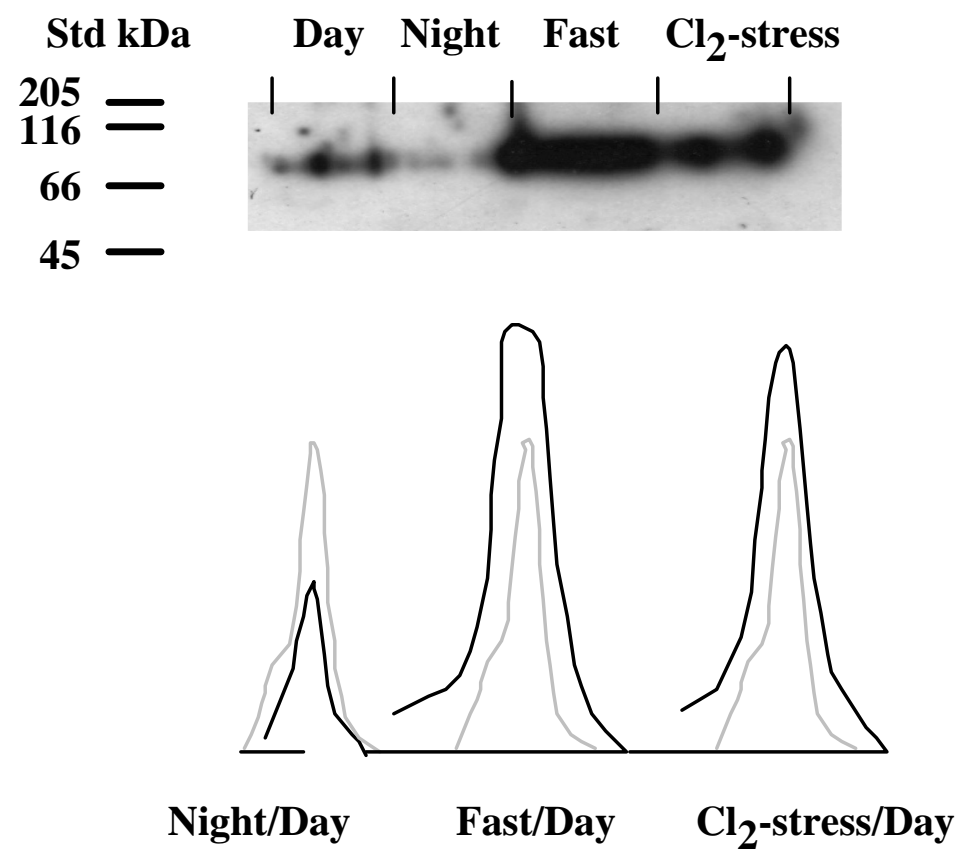